\title{
航空发动机整流罩新型防冰方法
}

\author{
宣益民*，连文磊 \\ 南京航空航天大学, 航空发动机热环境与热结构工业和信息化部重点实验室, 南京 210016 \\ * 联系人, E-mail: ymxuan@nuaa.edu.cn
}

2016-04-05 收稿, 2016-05-04 修回, 2016-05-09 接受, 2016-07-01 网络版发表

\begin{abstract}
摘要在一定的飞行条件和气象条件下, 航空发动机的进气部件会出现结冰现象, 导致发动机性能恶化甚至危 及安全. 目前, 防止发动机结冰的方法主要包括压气机热气防冰和电加热防冰, 不可避免地要消耗用于做功的高 压空气或高品位电能. 本文开展利用发动机废热防止整流罩结冰的高效低能耗的新型防冰方法研究. 提出了一种 旋转整流罩热管防冰系统结构, 建立了描述旋转整流罩热管防冰系统流动与传热现象的数学模型与设计方法, 研 制了典型旋转整流罩热管防冰系统原理样机; 系统地开展了旋转整流罩热管防冰系统性能的数值模拟和冰风洞 条件下样机防冰性能的实验验证, 分析研究了发动机转速和传热量等因素对发动机整流罩热管防冰系统性能的影 响. 结果表明, 本文建立的旋转整流罩热管防冰性能模型可以较好地预测防冰系统的性能, 建立的防冰样机满足 设计气象条件下的防冰要求, 证明了旋转整流罩热管防冰技术的可行性.
\end{abstract}

关键词旋转热管, 整流罩, 防冰, 数值模拟, 冰风洞实验

飞机在结冰气象条件下飞行时, 航空发动机的 进口部件, 如整流罩、进气道等容易出现结冰现象. 发动机结冰会改变进气道的气动形状, 引起速度场 畸变或气流局部分离; 结冰还会减小进人发动机的 空气流量, 从而导致发动机推力下降; 如果发生冰脱 落, 甚至会造成发动机的损毁, 使飞机的飞行安全受 到威胁 ${ }^{[1,2]}$. 目前航空发动机的防冰系统多采用热气 防冰和电加热防冰技术 ${ }^{[3]}$. 热气防冰是从压气机引出 热空气加热部件表面以防止结冰, 由于消耗了用于 做功的高压空气, 会导致发动机性能和效率下降. 例 如, 从发动机高压压气机最后一级引气 $1 \%$, 会导致 发动机推力减小约 $3 \%{ }^{[4]}$. 电加热防冰将电能转变为 热能从而有效加热防冰表面, 但不可避免地要消耗 数量可观的高品位能量. 航空发动机特有的高可靠 性、低油耗的性能目标, 对防冰系统提出了更高的要 求. 如何满足高效、可靠、低能耗的防冰需求, 保障 发动机稳定、安全工作的同时降低燃油消耗, 是当今
民用航空发动机设计和运行中的主要问题之一, 也 是未来高性能航空发动机研制中亟待解决和突破的 关键问题之一.

发动机正常工作时产生大量的废热, 通过各种 方式散发至环境. 如果能将部分废热(例如润滑油 热、高压空气热)作为抑制冰形成的热源, 利用高效 的传热机构将热量从热源稳定传输到发动机整流罩 表面, 也可以实现防除冰的目的.一种可能选择的高 效传热元件是依靠内部工质气液两相循环实现热量 传递的热管 ${ }^{[5]}$. 对于发动机的旋转部件, 可利用旋转 热管原理 ${ }^{[6,7]}$ 实现转子轴向热量的高效传输. 如果将 旋转热管集成于整流罩的旋转轴, 可以借助整流罩 的自转将发动机废热传递至其冷表面, 从而实现防 冰目的. 相比于传统的防冰手段, 采用旋转热管的防 冰技术具有以下优点: 不需要从压气机引气，不影响 发动机工作效率; 不需要额外的能量输人; 防冰的 同时兼顾滑油冷却(利用滑油废热时)或发动机中冷

\footnotetext{
引用格式: 宣益民, 连文否. 航空发动机整流罩新型防冰方法. 科学通报, 2016, 61: 2843-2850 Xuan Y M, Lian W L. A new anti-icing method for an aero-engine nose cone (in Chinese). Chin Sci Bull, 2016, 61: 2843-2850, doi: 10.1360/N972016-00445
} 
(利用高压空气废热时); 热管结构简单, 无运动部件, 可靠性高.

航空发动机热管防冰技术的相关研究很少. 2009 年, Gilchrist ${ }^{[8]}$ 曾提出了一种利用旋转热管实现整流 罩防冰的设想, 采用广泛应用于旋转热管传热性能 研究的一维膜状冷凝/蒸发模型 ${ }^{[6 ~ 10]}$ 描述热管内液体 的流动传热过程, 在忽略蒸汽复杂流动影响的简化 条件下, 计算分析了整流罩防冰的能力. 这种简化的 理论模型不能深入揭示旋转热管内的两相流动与传 热机理, 特别是分析旋转热管内蒸汽的复杂流动及 其对液体流动的影响、惯性离心力场诱导的蒸发段液 体自然对流特性等, 使得对整流罩热管防冰系统运 行特性的理论分析存在较大的局限性, 难以准确预 测其防冰性能; 此外, 所设想的热管结构复杂, 难以 维持稳定的两相循环流动, 因而并未开展相关的实 验研究以验证该设想.

总体上, 虽然热管防冰技术具有很好的应用前 景, 但旋转热管内部两相流动和相变传热过程十分 复杂, 迄今尚未建立较为完善的理论模型以深人揭 示惯性离心力、表面张力、相变驱动力、黏性力、物 性变化等综合作用下的液气两相循环和能量传递规 律, 这为整流罩热管防冰系统性能的理论分析和设 计带来了很大的挑战. 正是由于缺乏可靠的设计方 法与实验验证, 未见发动机热管防冰应用实例及实 验研究的相关报道, 其可行性仍得不到证实. 因此, 对旋转整流罩热管防冰系统开展深人的理论和实验 研究, 具有重要的学术价值和工程意义.

本文针对航空发动机旋转整流罩开展热管防冰 方法研究, 首先提出一种旋转整流罩热管防冰结构; 建立描述旋转整流罩热管防冰系统两相流动与传热 宏观现象的数学模型, 通过数值模拟揭示旋转整流 罩热管防冰系统的运行特性; 在此基础上研制典型 旋转整流罩热管防冰系统的原理样机, 开展样机防 冰性能的冰风洞验证实验. 研究目的旨在深人揭示 旋转整流罩热管防冰系统的传热机理及性能影响机 制, 从而建立旋转整流罩热管防冰系统的设计方法, 以及实验验证整流罩热管防冰技术的可行性.

\section{1 模型建立}

本文提出了一种旋转整流罩热管防冰结构, 如 图1所示. 图中阴影区域为固体域, 空白区为流体域, 发动机整流罩内壁为圆雉面, 热管冷凝端部具有与

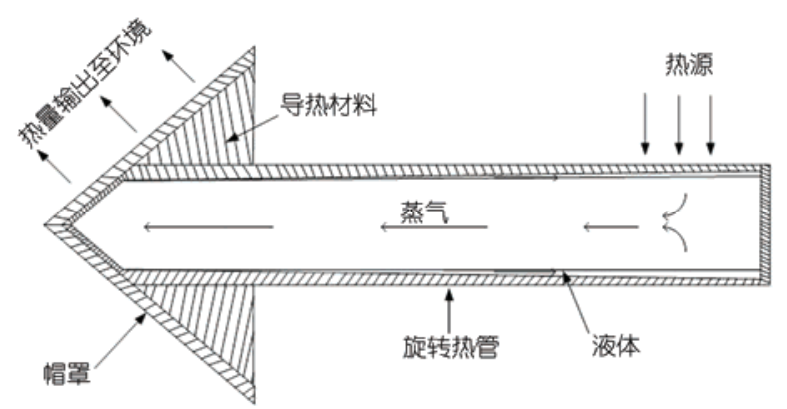

图 1 旋转整流罩热管防冰系统示意图

Figure 1 Schematic of the rotating nose cone anti-icing system based on a RHP

整流罩内壁相同的雉度以方便配合, 蒸发段和绝热 段为圆筒结构, 内径自蒸发段至冷凝段逐渐减小. 在 整流罩和热管之间填充轻型导热材料, 以减小热管 与整流罩之间的热阻. 为了保证低温环境下的正常 运行, 采用低温工质(如乙醇等). 热管可装配于发动 机转轴内部, 由发动机转轴带动其旋转, 以高温滑油 或高压空气作为热源. 发动机工作时热源温度高于 环境温度, 热管蒸发段液体吸热蒸发, 蒸汽在压差的 作用下到达冷凝端放热凝结, 冷凝液在旋转离心作 用下回到蒸发段, 周而复始, 持续循环, 热量由热源 传递至整流罩外表面而防止其结冰.

为了建立整流罩热管防冰系统性能的设计方法, 需要明确该系统的热量传递特性, 对旋转热管内部 工质的流动与传热、管壳的导热, 以及填充材料与整 流罩的导热进行理论分析, 其中的重点在于旋转热 管内部工质的流动和传热过程. 旋转热管内部工质 受到旋转速度、传递的热流密度、物性参数等因素的 影响, 在旋转惯性力、表面张力、相变驱动力、黍性 力等综合作用下, 通过气液两相的循环实现热量传 递. 旋转热管传热特性理论研究的重点在于揭示上 述因素如何作用于流体的流动和传热过程, 如何影 响整流罩热管防冰系统的能力, 以及如何利用各影 响因素的匹配以实现良好的防冰性能. 为此, 本文基 于连续介质假设, 从流体力学和传热学理论出发, 考 虑惯性离心力、表面张力、黏性力、相变过程等对旋 转热管液气流动和传热特性的影响, 建立描述整流 罩热管防冰系统工质两相流动、相变传热，以及固体 导热过程的宏观数学模型, 通过数值模拟研究整流 罩热管防冰系统性能的影响机制, 为防冰系统的设 计提供理论基础.

我们在前期研究中曾采用欧拉-欧拉多相流模 
型, 将液体和蒸汽作为一个整体的区域, 建立了包含 完整 N-S 方程组的液气两相流动与相变传热传质数 学模型, 针对典型旋转热管的流动和传热特性开展 了数值模拟研究, 模型预测结果与实验结果吻合较 好, 证明了模型的可靠性 ${ }^{[11]}$. 本文采用该模型描述 整流罩热管防冰系统工质的流动与传热过程, 在动 量守恒方程中定义源项, 模拟表面张力、由不均匀惯 性离心加速度和流体密度随温度变化而导致的浮升 力, 模拟液气的流动特性及相互作用; 追踪相界面, 建立气液相变模型 ${ }^{[11]}$, 在相界面单元定义连续性方 程的源项, 模拟气液相变过程的相间质量传递, 定义 能量守恒方程的源项, 模拟蒸发和冷凝过程产生的 相间能量传递. 由于防冰系统关于中心线具有对称 性, 假设旋转热管运行时各物理量无周向梯度, 旋转 运动通过在动量方程中定义离心力实现, 采用二维 轴对称模型对该系统进行数值模拟, 如图2所示.

流体的动量边界定义为无滑移边界, 流体和固 体界面设为耦合壁面条件, 初始条件全场速度为零, 温度为 $300 \mathrm{~K}$. 首先分析了不同转速 $(1000,2000$, $3000 \mathrm{r} / \mathrm{min})$, 不同传热量 $(500,1000,2000,3000 \mathrm{~W})$ 下 整流罩热管防冰系统的传热性能, 蒸发段和整流罩 外壁面定义为恒定热流边界. 然后对典型气象条件 下的防冰系统性能进行模拟, 热源采用滑油, 温度为 $94^{\circ} \mathrm{C}$, 来流空气速度为 $93 \mathrm{~m} / \mathrm{s}$, 空气温度为 $-10^{\circ} \mathrm{C}$, 空 气中的液态水含量为 $2 \mathrm{~g} / \mathrm{m}^{3}$, 水滴平均直径为 $20 \mu \mathrm{m}$; 蒸发段外壁面采用第三类热边界条件, 来流温度为 滑油温度, 换热系数定义为不同值以进行对比分析; 整流罩外壁面定义为第三类热边界条件, 来流温度 为空气温度, 换热系数分布根据整流罩在定温条件 下与来流空气的温差以及该条件下的防冰热载荷 ${ }^{[12]}$ 计算求得, 反映了空气对流换热和水滴撞击吸热共 同作用的结果.

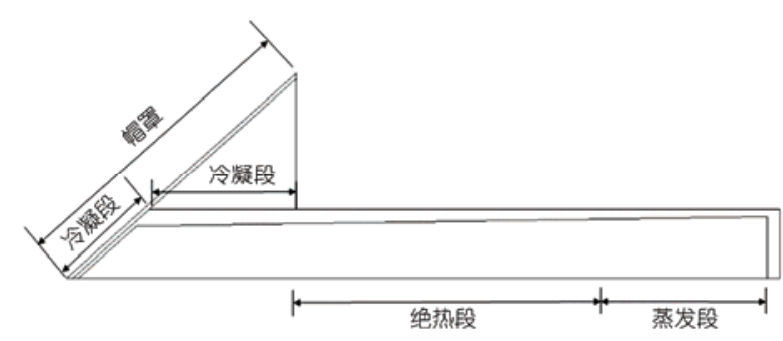

图 2 旋转整流罩热管防冰系统几何模型

Figure 2 Computational domain of the rotating nose cone anti-icing system based on a RHP

\section{2 数值模拟}

首先通过数值模拟研究了整流罩热管防冰系统 在不同旋转速度和不同传热量下的运行特性. 随着 系统传热量的增大, 蒸发段和整流罩的平均温差也 随之增大，而温差随转速的提高有所下降. 图3表示 了防冰系统总热阻 $R$ 与传热量 $Q$ 和转速 $n$ 的关系, 总 热阻由下式计算:

$$
R=\frac{T_{\mathrm{e}}-T_{\mathrm{c}}}{Q},
$$

其中, $T_{\mathrm{e}}$ 表示蒸发段外壁面的平均温度，单位为 $\mathrm{K}$; $T_{\mathrm{c}}$ 表示整流罩外壁面的平均温度, 单位为 $\mathrm{K} ; Q$ 表示 防冰系统传递的热量, 单位为 $\mathrm{W}$; 总热阻 $R$ 单位为 $\mathrm{K} / \mathrm{W}$. 由图3可见, 随着传热量的增大, 防冰系统的 总热阻下降, 高转速下尤其明显, 这是因为传热量增 大强化了工质的自然对流换热, 这种影响随着转速 的提高(惯性离心力增大)而更加显著. 转速较低时, 系统的总热阻随转速的提高而显著降低; 在高转速 下, 总热阻的下降幅度相对较小. 总之, 防冰系统的 总热阻随转速提高和传热量增大而下降. 针对发动 机的具体工况, 可以根据其转速和所需要的防冰热 载荷确定总热阻, 如果总热阻小于该工况下的热阻 上限 (由冷热源温度和防冰热载荷确定), 系统才具备 防冰的前提.

针对典型气象条件(来流空气速度 $93 \mathrm{~m} / \mathrm{s}$, 温度 $-10^{\circ} \mathrm{C}$ ), 对旋转热管防冰系统的性能进行数值模拟, 蒸发段外部来流温度取对应工况下的滑油温度, 表 面传热系数 $h$ 取不同值进行计算研究, 整流罩外部来 流温度取来流空气温度, 表面换热系数由防冰热载

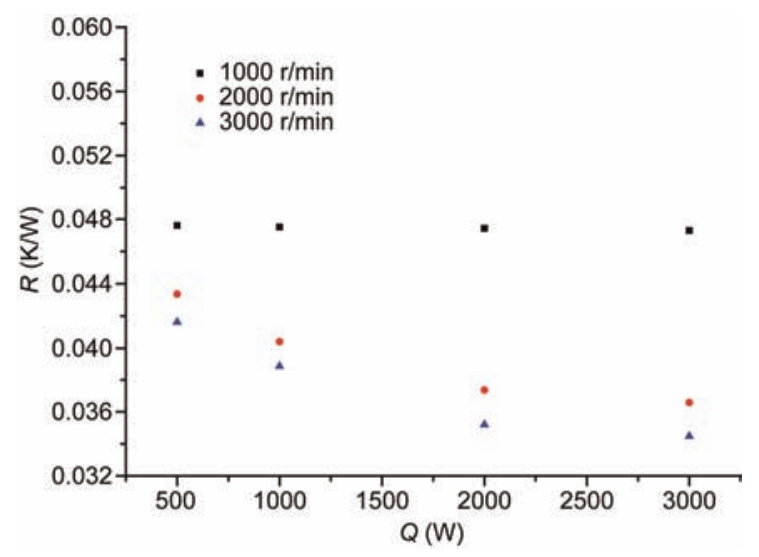

图 3 (网络版彩色)防冰系统总热阻随传热量和转速的变化

Figure 3 (Color online) Change in the total thermal resistance of the anti-icing system with heat transfer rate and rotational speed 
荷计算过程求得. 整流罩与热管之间填充材料的导 热系数 $k$ 取不同值进行研究. 图4所示为防冰系统的 传热量计算结果, 横坐标为蒸发段与热源之间的表 面换热系数, 参考变量为填充材料的导热系数, 单位 是 $\mathrm{W} / \mathrm{mK}$, 虚线表示该工况下的防冰热载荷目标值. 由图4可见, 防冰系统的传热量随 $h$ 和 $k$ 的增大而增加, 提高这两个参数都有利于系统总热阻的减小和传热 量的增大. 填充导热材料后, 系统的传热量显著增 大, 这得益于冷凝段并联了填充材料的导热热阻, 总 热阻显著下降; 随着导热系数 $k$ 增大, 传热量进一步 增大. 在其中 5 种条件下, 计算得到的系统实际传热 量大于防冰热载荷目标值, 但是, 要分析各条件下系 统的防冰可行性, 还要分析整流罩外表面的温度分 布情况.

整流罩外表面温度分布特性如图5所示, 横坐 标表示整流罩表面点与驻点的无量纲距离, 纵坐 标为该点温度值. 在整流罩靠近驻点的约 $1 / 3$ 区域, 整流罩温度维持在比较高的水平, 而且最高点在 该区域的中间位置, 这是因为在该区域内, 驻点 处整流罩表面与环境之间的换热系数最高, 换热 强度最大, 换热系数向周边逐渐降低, 因此最高 温点与驻点有一定距离. 在靠近驻点 $1 / 3$ 区域以外, 温度显著下降, 整流罩整体温度分布不均匀. 填 充导热材料后, 中心高温区的温度下降, 外围区 域温度上升, 整流罩的均匀性得到很大改善, 随 着填充材料导热系数的增大, 整流罩均匀性提高, 整流罩高于结冰点的区域明显增大. 蒸发段表面

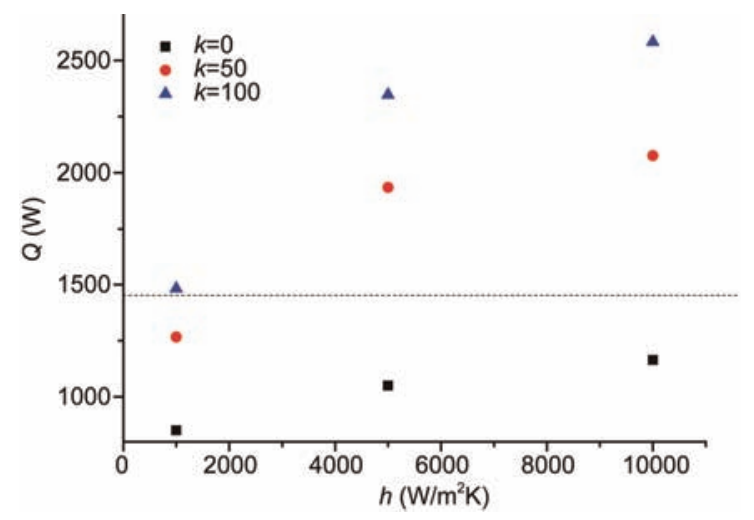

图 4 (网络版彩色) 实际工况下的防冰系统传热能力 $(v=93 \mathrm{~m} / \mathrm{s}, T=$ $-10^{\circ} \mathrm{C}$ )

Figure 4 (Color online) Heat transfer capacity of the anti-icing system under a real operation condition $\left(v=93 \mathrm{~m} / \mathrm{s}, T=-10^{\circ} \mathrm{C}\right)$

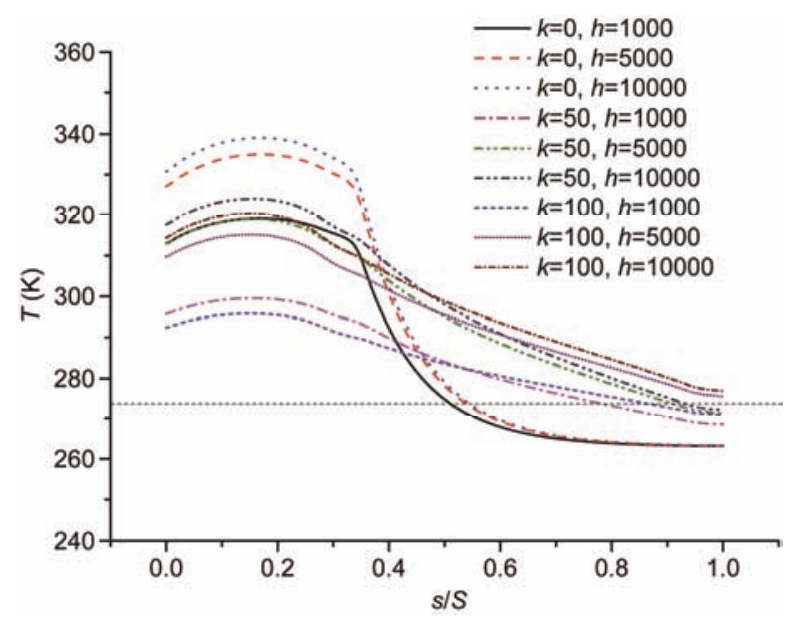

图 5 (网络版彩色)整流罩外表面温度分布特性 $\left(v=93 \mathrm{~m} / \mathrm{s}, T=-10^{\circ} \mathrm{C}\right)$

Figure 5 (Color online) Temperature distribution on the outer wall of the nose cone $\left(v=93 \mathrm{~m} / \mathrm{s}, T=-10^{\circ} \mathrm{C}\right)$

传热系数的增大则导致整流罩表面温度的整体上 升. 填充材料导热系数为 $100 \mathrm{~W} / \mathrm{mK}$, 蒸发段表面 传热系数为 5000 和 $10000 \mathrm{~W} /\left(\mathrm{m}^{2} \mathrm{~K}\right)$ 时, 整流罩整个 表面的温度高于结冰点, 具有防止结冰的能力. 实际应用中, 只要保证填充材料在主要传热方向 上的导热系数高于上述需求, 考虑扩展蒸发段外 表面积以减小传热系数的需求, 从而提高工程可 实现性.

\section{3 原理样机实验研究}

理论研究结果说明旋转整流罩热管防冰系统 具有防冰的可能性, 本文研制了整流罩热管防冰 系统原理样机, 对其防冰能力进行冰风洞实验验 证. 图6所示为防冰系统原理样机主要部分的实物 图. 旋转控制系统由无霍尔直流电动机、 Invt Goodrive 300驱动器、弹性联轴器, 以及轴承等组 成. 电动机功率 $3.7 \mathrm{~kW}$, 额定扭矩 $5 \mathrm{Nm}$, 转速范围 为 $0 \sim 10000 \mathrm{r} / \mathrm{min}$. 电机通过驱动轴将动力传递至 热管, 驱动轴一端依靠正旋螺纹与热管配合, 另 一端依靠弹性联轴器与电机同轴连接. 热管轴向 装配 2 对轴承以支撑实验本体, 轴承内圈和热管之间 由聚四氟乙烯套过渡, 以减少热量散失. 采用电阻 型加热器向热管提供热源, 热功率由IT6726型直流 稳压电源控制和监测, 加热器与热管壁通过热辐射 和空气对流的方式传递热量, 外部加装硅酸铝 


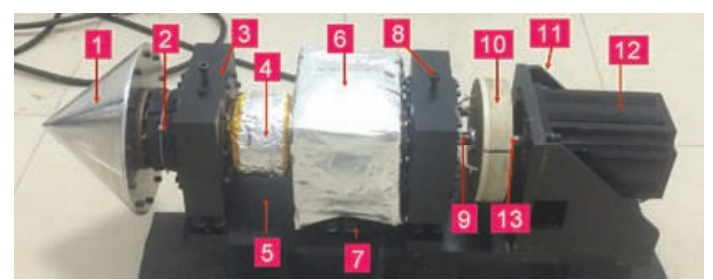

图 6 (网络版彩色)整流罩热管防冰系统原理样机实物图. 1 整流罩; 2,4 绝热层; 3,8 轴承及支座; 5 底座; 6 电加热器; 7 加热器支架; 9 样机 转轴; 10 数据采集及发射装置; 11 电动机支座; 12 电动机; 13 联轴器

Figure 6 (Color online) Prototype of the nose cone anti-icing system based on a RHP. 1 Nose cone; 2,4 heat insulator; 3,8 bearing and support; 5 base; 6 electric heater; 7 support of the heater; 9 rotating shaft; 10 data acquisition and launch system; 11 support of the electric motor; 12 electric motor; 13 coupling

保温材料, 避免热量损失. 热管管壁温度采用 $\mathrm{K}$ 型 热电偶测量, 电势差信号经补偿电路处理后再通 过数据无线传输模块将信息转换成无线电波由天 线发射端发射, 再由与计算机相连的无线接收端 接收.

旋转热管管壳为紫铜, 工质为无水乙醇, 采用 抽真空工艺进行充液. 管内径自蒸发段至冷凝段 由大变小, 冷凝端部为圆雉面, 其内部雉度与外 部保持一致, 内部有平直肋片结构以扩大冷凝面 积. 热管热端有螺纹结构以安装驱动轴, 管外有 法兰结构以安装整流罩. 整流罩材料为铝合金, 雉 度 $80^{\circ}$, 厚度 $5 \mathrm{~mm}$, 边缘有 12 个螺纹孔以进行装配. 在整流罩和热管的空隙处填充了纯铜多孔材料, 其 有良好的热传导性能且密度适中, 如图7所示.

样机安装于风筒内组成冰风洞实验段, 如图8 所示. 风筒内径 $600 \mathrm{~mm}$, 长度 $1 \mathrm{~m}$, 右前方开玻璃 视窗, 视窗框内有热气通道和喷射孔, 与热气管 道连接以加热玻璃防止视窗结冰. 风筒作为冰风 洞的一段安装在A617冰风洞实验台上, 侧面架设

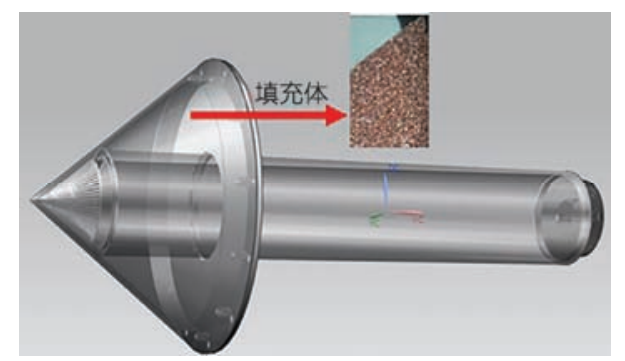

图 7 (网络版彩色)整流罩和热管装配效果图

Figure 7 (Color online) Assembly drawing of the nose cone and the RHP

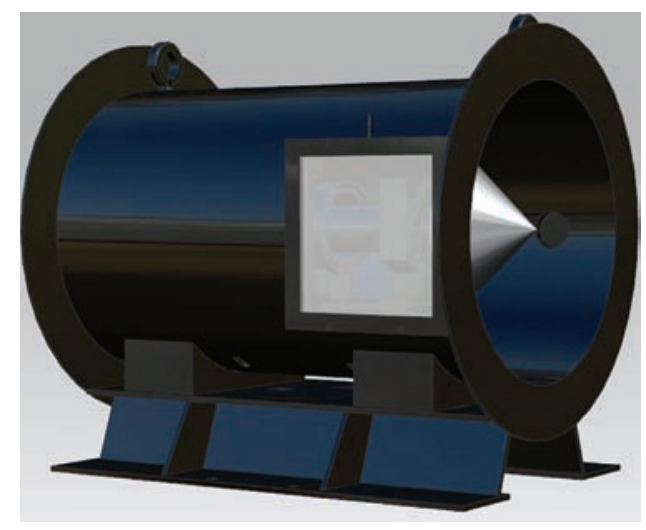

图 8 (网络版彩色) 冰风洞实验段

Figure 8 (Color online) Experimental section of the ice wind tunnel

IDT公司的Y4高速相机对整流罩进行拍照. 在实验 段视窗一侧用功率 $100 \mathrm{~W}$ 的LED灯作为照明光源.

对样机在发动机结冰工况下的性能开展了冰 风洞实验研究. 实验时先开启风洞, 调节参数使 其达到目标值, 同时开启电机和热源, 使样机达 到转速目标值，控制加热量保证热管蒸发段外壁 面温度不超过相应工况的计算结果 (即以滑油作为 热源时蒸发段外壁面温度). 待样机和风洞参数稳 定，开始喷雾并记录整流罩结冰过程. 图9所示为 发动机转速 $3200 \mathrm{r} / \mathrm{min}$, 来流风速 $93 \mathrm{~m} / \mathrm{s}$, 气温 $-10^{\circ} \mathrm{C}$, 液态水含量 $2 \mathrm{~g} / \mathrm{m}^{3}$ 工况下的对比组实验结 果, 热源处于关闭状态, 从而确定整流罩的结冰 情况. 图10所示为样机工作状态下的结果, 整流 罩表面未见结冰.

实验结果表明，在未施加防冰手段的条件下， 整流罩表面迅速结冰, 冰层厚度大且不均匀, 表 面有明显凸起，会对空气流场产生影响. 防冰系 统样机启动后, 系统表现出明显的防冰效果, 从 能量传递角度验证了旋转整流罩热管防冰技术的 可行性.

\section{4 结论}

本文提出了一种基于旋转热管技术的航空发动 机整流罩防冰系统结构, 建立了整流罩热管防冰系 统能量传递的数学模型, 数值模拟了旋转整流罩热 管防冰系统的工作特性, 获得了热管防冰系统性能 的影响机制和设计方法. 结果表明, 旋转整流罩热 管防冰系统的传热性能受转速、传热量等因素的影 


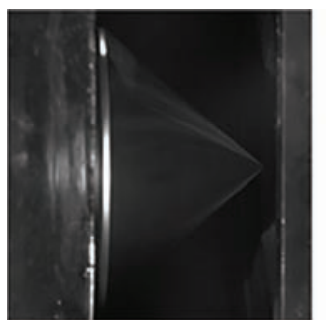

Os

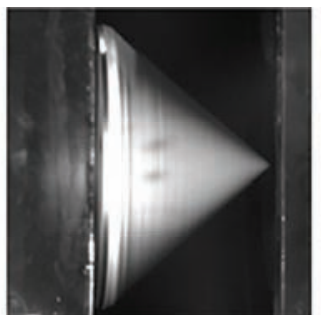

$60 \mathrm{~s}$

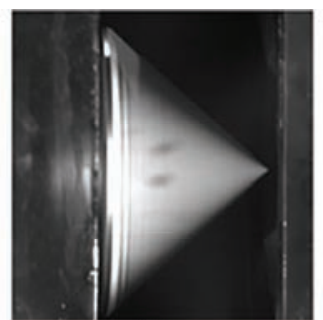

$120 \mathrm{~s}$

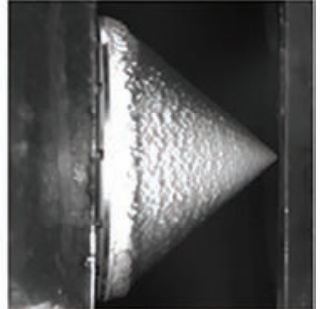

$210 \mathrm{~s}$

图 9 整流罩结冰过程 $\left(v=93 \mathrm{~m} / \mathrm{s}, T=-10^{\circ} \mathrm{C}\right.$, 对比组)

Figure 9 Icing procedure of the nose cone $\left(v=93 \mathrm{~m} / \mathrm{s}, T=-10^{\circ} \mathrm{C}\right.$, reference operating condition)

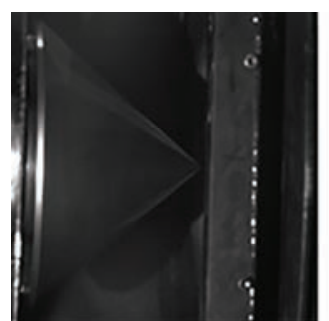

Os

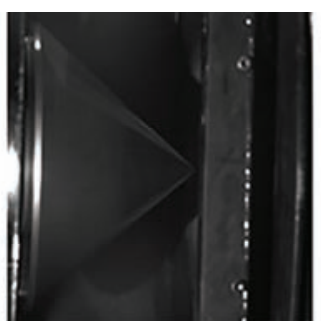

$60 \mathrm{~s}$

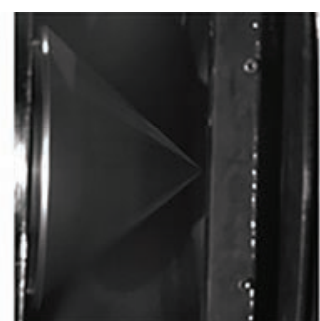

$120 \mathrm{~s}$

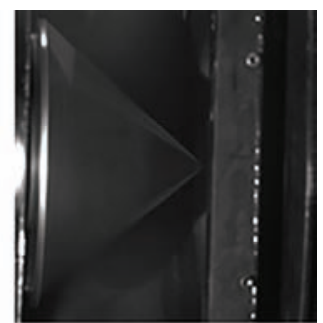

$210 \mathrm{~s}$

图 10 整流罩防冰过程 $\left(\nu=93 \mathrm{~m} / \mathrm{s}, T=-10^{\circ} \mathrm{C}\right)$

Figure 10 Anti-icing performance of the nose cone $\left(v=93 \mathrm{~m} / \mathrm{s}, T=-10^{\circ} \mathrm{C}\right)$

响, 其总热阻随传热量的提高和转速的提高而下 降; 整流罩与热管直接接触的区域温度高且相对均 匀, 离开热管的区域温度迅速下降, 热管与整流罩 之间填充材料的导热性能是影响整流罩温度均匀 性的关键因素; 蒸发段与滑油之间传热系数的增大 导致整流罩温度的整体上升; 要使整流罩外表面所 有区域温度高于结冰点, 需要足够高的填充材料导
热系数和蒸发段外表面换热系数. 研制了整流罩热 管防冰系统原理样机, 开展了样机的冰风洞实验, 结果表明, 在未施加防冰手段的条件下, 整流罩表 面迅速结冰, 冰层厚度大且不均匀, 防冰系统样机 工作后表现出明显的防冰效果. 本文通过理论和实 验研究, 从能量传递角度验证了发动机旋转整流罩 热管防冰新技术的可行性.

\section{参考文献}

1 McVey O, Pullen R. Inclement weather and aircraft engine icing. In: Proceedings of SAE aircraft engine icing conference and exhibition. Seville, 2007

2 Graversen P. Grand based measuring and warning of weather conditions in which engine icing may occur. In: Proceedings of SAE aircraft engine icing conference and exhibition. Seville, 2007

3 Qiu X G, Han F H. Aircraft Anti-Icing System (in Chinese). Bejing: Aviation Professional Teaching Materials Editing Group, 1985 [雸 焂纲，韩风华.飞机防冰系统. 北京: 北京航空教材编审组, 1985]

$4 \mathrm{Hu}$ Y P. Numerical simulation on the ice accretion of the entry components of an aero-engine (in Chinese). Dissertation for Doctoral Degree. Nanjing: Nanjing University of Aeronautics and Astronautics, 2009 [胡娅萍. 航空发动机进口部件积冰的数值模拟研究. 博 士学位论文. 南京: 南京航空航天大学, 2009]

5 Faghri A. Heat Pipe Science and Technology. London: Taylor \& Francis Publishing Company, 1995

6 Bertossi R, Guilhem N, Ayel V, et al. Modeling of heat and mass transfer in the liquid film of rotating heat pipes. Int J Therm Sci, 2012, 52: $40-49$

7 Jankowski T A. Numerical and experimental investigations of a rotating heat pipe. Dissertation for Doctoral Degree. Albuquerque: The University of New Mexico, 2007 
8 Gilchrist S, Ewing D, Ching C Y. On the design of an aero-engine nose cone anti-icing system using a rotating heat pipe. J Therm Sci Eng Appl, 2009, 1: 1-11

9 Hassan H, Harmand S. Effect of using nanofluids on the performance of rotating heat pipe. Appl Math Modelling, 2015, 39: 4445-4462

10 Song F, Ewing D, Ching C Y. Fluid flow and heat transfer model for high-speed rotating heat pipes. Int J Heat Mass Tran, 2003, 46: 4393-4401

11 Lian W L, Chang W, Xuan Y M. Numerical investigation on flow and thermal features of a rotating heat pipe. Appl Therm Eng, 2016, 101: 92-100

12 Zhao L. Investigation on the ice accretion characteristics and anti-icing heat loads of the aero-engine nose cone (in Chinese). Dissertation for Master Degree. Nanjing: Nanjing University of Science and Technology, 2015 [赵否. 航空发动机整流罩结冰特性及防冰热载荷的 分析研究. 硕士学位论文. 南京: 南京理工大学, 2015] 


\title{
A new anti-icing method for an aero-engine nose cone
}

\author{
XUAN YiMin \& LIAN WenLei \\ Key Laboratory of Aero-engine Thermal Environment and Structure, Ministry of Industry and Information Technology, Nanjing University of \\ Aeronautics and Astronautics, Nanjing 210016, China
}

Ice accretion may occur on the entry components of an aero-engine under certain weather and flight conditions, which would lead to the deterioration of the engine performance and even severe safety problems. Anti-icing systems have been used including hot air anti-icing system, which consumes high pressure air from the compressor, and electronic heating system, which consumes high grade electronic energy. Compared with the traditional anti-icing methods, an efficient and low energy consumption anti-icing technique based on the rotating heat pipe (RHP) has a great advantage and good application potential, which utilizes the waste heat of the aero-engine. Until now, however, the mechanism of the heat transfer in a RHP has not been clearly revealed yet, due to the complexity of the two phase flow and phase change process occurred in the RHP, which makes it difficult to establish the design method for the aero-engine anti-icing system based on a RHP. Furthermore, the feasibility of the anti-icing system based on a RHP has not been confirmed by experiments. Therefore, the present work is focused on the theoretical and experimental investigations on the rotating nose cone anti-icing technique based on a RHP, in order to explore the two phase flow and heat transfer mechanism of such an anti-icing system, and to reveal the effects of different parameters on the performance of the system, which may provide the theory basis for the design of the nose cone anti-icing system based on a RHP. Furthermore, it is expected that the feasibility of the anti-icing system based on a RHP can be confirmed by the experiments on a prototype, providing the basis for the engineering applications.

In this study, a nose cone anti-icing structure based on a RHP has been proposed, and the mathematical model based on the complete Navier-Stokes equations was established to explore the details of fluid flow and heat transfer in the anti-icing system. The volume of the fluid (VOF) model was employed for the simulation of two phase flow, and a new phase-change model was introduced to predict the evaporation and condensation processes in the RHP while the balance between the evaporative and condensing masses was considered. Numerical simulations have been carried out to study the operation characteristics of the system. The impact of parameters such as the rotational speed, the heat transfer rate, heat conductivity of the filler and heat transfer coefficient between the heat pipe and heat source on the performance of the anti-icing system have been examined. A prototype of the nose cone anti-icing system based on a RHP has been developed for the ice wind tunnel tests. The results indicated that the anti-icing system has the ability to maintain the temperature of the nose cone above the freeze point under certain conditions. It is found that the theoretical model can be used to predict the performance of the nose cone anti-icing system based on a RHP, and the prototype has a satisfactory anti-icing performance. The investigations laid a solid foundation for the engineering applications of the anti-icing technique based on RHPs.

rotating heat pipe, nose cone, anti-icing, numerical simulation, ice wind tunnel test

doi: 10.1360/N972016-00445 